International Journal of Child, Youth and Family Studies (2015) 6(4): 595-621

\title{
THE CANONICAL SELF AND POLITICIZED PRAXIS: A TRACING OF TWO CONCEPTS
}

\section{Scott Kouri}

\begin{abstract}
This article maps various conceptualizations of the self and praxis in child and youth care theory. With specific reference to the curriculum and pedagogy developed at the School of Child and Youth Care at the University of Victoria, the shift from the knowledge, skills, self (KSS) model to the praxis framework is argued to exemplify a move to a more dynamic and politically nuanced rendering of the concept of the self relative to its more canonical expressions. The canonical self of CYC is proposed here as an aggregate of the writings of a small group of CYC theorists that together constitute the dominant conceptualization of the self in the field's literature. Historical and philosophic context is provided for the articulation of the self in the canonical literature and a brief review of this literature is provided. The concept of politicized praxis builds on White's (2007) Praxis Framework, as well as the work of other CYC theorists and practitioners (e.g., de Finney, Dean, Loiselle, \& Saraceno, 2011; Gharabaghi \& Krueger, 2010; SkottMyhre \& Skott-Myhre, 2011), to propose an avenue of theoretical development that might more adequately respond to the realities and experiences of diverse children, youth, and families. As a review this paper critically reflects on CYC's theoretical traditions; as an opening gambit it proposes a way forward in theorizing a praxis that is responsive to the realities of contemporary society.
\end{abstract}

Keywords: Child and Youth Care, self, praxis, theory, KSS model, context, political

Acknowledgement: This research was supported by the Social Sciences and Humanities Research Council of Canada.

Scott Kouri is a Ph.D. student and instructor at the School of Child and Youth Care, University of Victoria, P.O. Box 1700, STN CSC, Victoria, B.C., Canada, V8W 2Y2. He works as a clinical counsellor and youth worker. Scott's research focus is related to politicized CYC praxis and how concepts of the self, identity, and subjectivity are circulated in CYC curricula. E-mail:

skouri@uvic.ca 
International Journal of Child, Youth and Family Studies (2015) 6(4): 595-621

The praxis framework (White, 2007) is quickly becoming a guiding pedagogical force at the School of Child and Youth Care, University of Victoria, as well as across North American Child and Youth Care (CYC). Building on the earlier knowledge, skills, self (KSS) framework, while transforming some of its central components, praxis offers us a way of integrating theory and practice in complex, shifting, and politically charged contexts. In such contexts White (2007) proposes that the concept of "ways of being”, as an active and dynamic rendition of the concept of the "self”, allows for relational and ethical accounts of practitioners' being in the world. This paper proposes that a close tracing of the concept of the self through CYC's rich literature and into the current praxis framework can help us map our theoretical and pedagogical past and future possibilities. I therefore chart conceptual approaches to the self in North American CYC literature, curricular, and professional development, and Western philosophy more generally. While a full account of these dimensions of the concept of the self is beyond the scope of this paper, I do provide a tracing of these ideas that connects our theoretical lineage to a proposal for further development to the praxis framework. I begin by providing a context for the paper by outlining a history of the concept of the self in CYC curriculum and professionalization. Next I provide a very brief genealogy of the self in Western philosophy, elaborate my concept of the canonical self, and engage with the central CYC literature on the topic. I close the paper by providing an account of the transition that occurred in 2007 at SCYC from the KSS model to the praxis framework and argue for further developments in line with a more politicized rendering of the self and praxis. This paper does not attempt an objective report on the state of affairs in the field or its literature but rather, as part of my own praxis, elaborates an account of my own thinking, practice, and hopes.

\section{The Concept of the Self in Early CYC Curriculum (1970 to 2000)}

Contemporary CYC is a practice approach to supporting the well-being of children, youth, and families. With roots in residential care, youth work, and developmental psychology, CYC has been developing as an academic program at School of Child and Youth Care (SCYC) since 1973 (Anglin, 1999; Pence, 1989). The field of CYC, inclusive of practice and academic domains, is generally concentrated on direct, caring, and holistic therapeutic relationships with children and youth informed by developmental, systems, and strengths-based theories (Anglin, 1999; Mattingly, Stuart, \& VanderVen, 2010). The self has featured as a core concept in the understanding of the caring relationship and the fully present practitioner, and has thus enjoyed a central place in CYC. White (2007), for example, describes one the hallmarks of CYC practice as "bringing oneself fully to the therapeutic relationship” (p. 225).

The concept of the self has been central to North American CYC for at least the past 40 years. Writings on the self, for example, constituted a large part of the curricula in the first Canadian degree program in CYC, then called the Child Care Program, which was offered at the University of Victoria (UVic). The early "knowledge, skills, self” (KSS) model (School of Child and Youth Care, 2011) and later "self-driven" (Garfat \& Ricks, 1995) and "self-awareness" (Ricks, 1989) models have been used to train practitioners and theorize practice, as well as to 
International Journal of Child, Youth and Family Studies (2015) 6(4): 595-621

differentiate CYC from other professions and academic disciplines (Anglin, 1999). In the field's early writings, the self, in addition to a state of being present that underlies caring relationships, was understood as the ethical cornerstone to practice (Garfat \& Ricks, 1995). Contemporary thinking continues in this tradition and views the self as the mediator of professional practice (Mattingly et al., 2010) and a lens through which we interpret (Garfat \& Charles, 2007).

North American CYC, based originally on the educator programs in Europe, became a distinct academic discipline in the 1960s and 1970s, in part through program development at UVic (Pence, 1989). The impetus for the development of a child care program at UVic, Pence explains, came predominantly from governmental and child service agencies requesting university-level training programs for child care workers. The Child Care Program was inaugurated at UVic in 1973 with a broad focus on training workers in child and adolescent service delivery and a specific focus on "residential and day centres, particularly those individuals with emotional, learning, and social adjustment problems” (Program description, May 1974, as cited in Pence, 1989). The School of Child Care, which delivered the program, gradually became the School of Child and Youth Care, and the program was later renamed Child and Youth Care. By the end of the 1970s, the scope of the practice field encompassed residential treatment, rehabilitation, early intervention, juvenile justice, child-life, child care, recreation, and work in communities (Denholm, Pence, \& Ferguson, 1983). Throughout the 1980s, SCYC developed individual courses with specific practice foci, as well as more encompassing frameworks. The first formal educational framework was the tripartite "knowledge, skills, self" (KSS) model (Pence, 1989) which featured in SCYC curriculum for decades to come and inaugurated an unprecedented concentration on the concept of the self.

The KSS model conceptualized the self in terms of the personal values, beliefs, and assumptions the practitioner brings into practice and the meaning-making process (Ricks, 1989). The undergraduate student handbook for SCYC (2011) described the self as the personal characteristics evidenced by presentations of thought, word, and action. In terms of training and curriculum, the handbook explained that learning about one's self involved developing awareness of thoughts, beliefs, values, communication, and actions. One of the distinguishing characteristics of CYC was thought to be the development of therapeutic or caring relationships that combined the personal and professional, which required "an integration of a complex constellation of knowledge, skills, and elements of self” (Anglin, 1999, p. 146). The self was viewed as the mediator of relationship; it comprised the personal characteristics that would facilitate therapeutic relationships, the framework for meaning-making, the driving force of actions and ethics, and the capacity of being present and reflective (Fewster, 1990; Garfat \& Ricks, 1995; Ricks, 1989, 1993). By the 1990s, a proliferation of writings, theories, and practice approaches inextricably tied the concept of the self to CYC.

Extending on the KSS model, theoretical developments in the late 1980s and the 1990s contributed to a more nuanced and operationalized view of the self that was related to ethics, awareness, relationship, and personal/professional development. Garfat and Ricks (1995) put forward a self-driven model of ethical decision-making in which the self of the practitioner informs and mediates the application of ethical codes and standards in specific contexts of practice. Frances Ricks (1989) advanced a self-awareness model that included self-image, 
International Journal of Child, Youth and Family Studies (2015) 6(4): 595-621

material, social, and spiritual aspects of the self, and a communicable knowledge of the self. Fewster $(1990,1999)$ offered personal experience and insights from psychology to explicate the self in its authentic and relational nature. Importantly, these authors continued to write about the self into the third millennium. The trend in CYC of emphasizing the importance of the self in theory and practice during the 1980s and 1990s was paralleled and further impelled by educational standardization and professionalization in CYC.

\section{Professionalization and Educational Standardization}

Beyond individual academic programs, the self, by the 1990s, was also gaining currency in larger CYC consortiums, credentialing organizations, and professional associations. Two influential organizational bodies in early North American CYC were the North American Consortium of Child and Youth Care Educational Programs (NACCYCEP) and the Association for Child and Youth Care Practice (ACYCP). These organizations led the way in consolidating and standardizing the definition, scope, and educational standards of CYC in North America, as well as mobilizing practitioners toward professionalization. The importance of the concept of the self was to resonate throughout these processes of standardization and professionalization.

NACCYCEP was formally established in 1990 with the purpose of advancing postsecondary CYC education. In 1995, Anglin published a special report on NACCYCEP's curriculum recommendations, which outlined what the consortium understood as the "unique and central” (p. 269) elements of post-secondary CYC education. The consortium's recommendations, drafted by Henry Maier, focused on the interactional and interpersonal aspects of CYC work and defined many of the key curricular elements in terms of the self. The recommendations included the development of curriculum to support a practitioner's "sense of self” (p. 271) and "professional use of self” (p. 272), arguing that, "the most effective interactions between workers and clients are based on relationships and the professional use of self" (p. 272). For NACCYCEP, the practice of care depended on the "use of self in shared experience” (p. 273). In 1998, Mark Krueger reported on NACCYCEP and advanced an interactive youth work curriculum that foregrounded "self in action" (Krueger, 1998, p. 68). Once the self was solidified as a central concept in North American CYC curricula, it quickly became important to professional standards and certification processes.

Between 2000 and 2007, ACYCP, a North American professional credentialing and research organization, sponsored the North American Certification Project (NACP) in developing a certification program for professionals (Eckles et al., 2009). To develop a professional certification, "the NACP defined the field of child and youth care practice, described the requisite knowledge and skills necessary for professional practice and established a method to assess competence” (p. 2). In 2010, ACYCP, through the work of its certification board, published standards and implemented a comprehensive certification program. Known as the competency document, the Competencies for Professional Child and Youth Work Practitioners (Mattingly et al., 2010) put forward a list of five professional competency areas and a framework for evaluating professional competence across five practice contexts. 
International Journal of Child, Youth and Family Studies (2015) 6(4): 595-621

As in the curriculum consortiums, the concept of the self was deeply embedded in the competency document and given a full exposition as one of the contexts for practice. Some examples of the self in the competency areas include being "self-directed" and "engaged in professional and personal development and self-care” (p. 10), having "self-awareness” (p. 11) and "self-understanding" (p. 12), and assessing relationships "in an ongoing process of self reflection about the impact of the self” (p. 18). Professional practice is explained in the document to focus "on the use of self as a mediator of knowledge and skills" (p. 27). Furthermore, the competency document dictates that "foundational to Child and Youth Care is the use of self, but to make effective use of self in practice one must first be aware of and able to articulate the nature of the self” (p. 28). The nature of the self, however, was not elaborated on, nor was the process of acquiring or evaluating such knowledge described beyond the professional educational standards of diploma or baccalaureate in CYC.

The competency document (Mattingly et al., 2010) has become the standard and central driving force in CYC professionalization in North America. Professionalization of the field, however, has not been achieved without significant criticisms and detractors. A recent volume (volume 43, issue 2) of one of the field's most high-impact journals, Child \& Youth Services, for example, specifically deconstructs, assesses, and, at times, criticizes professionalization. Although the definition of the field, its history, and its central concepts are debated and often disagreed upon, the concept of the self has been and continues to be central to CYC theory, curriculum, and professionalization.

Before engaging in review of the literature on the self in CYC, in the next section I provide a brief genealogy of the concept of the self in Western philosophy and sketch out my concept of the canonical self. I do so to more fully examine my own philosophic underpinnings and foundational assumptions of the concept of the self. I also specifically look to highlight the diversity of ways the self has been conceptualized and critiqued in order to open up new avenues for thinking about the self in the 21st century.

\section{Western Philosophic Context}

The Cartesian image of the self has dominated Western thinking for nearly 400 years. Throughout the second half of the second millennium AD, Western philosophy, espoused in the texts of predominantly Caucasian European Christian heterosexual males, travelled the globe through the vectors of colonialism and imperialism. Descartes (1637/1996), as a foundational thinker in Western philosophy, proposed a split between mind and matter and described the self as reflective, perceiving, questioning, and the foundation for knowledge. These claims of a mindmatter dualism and a self-reflective consciousness, although highly contested, have embedded themselves in many philosophical discourses on the self, including much of CYC theory.

The modern concept of the self in Western philosophy can be traced in variable form from classical Greek philosophy to Descartes' cogito. Plato (1992, trans.), in his dialogues on the death of Socrates, argued that the soul is immortal and distinct from the mortal body. The soul, for Plato, was a form that brought forth life in the material body and existed in another world after physical death. Aristotle (2008, trans.), highly indebted to Plato but divergent from the 
International Journal of Child, Youth and Family Studies (2015) 6(4): 595-621

latter's clear separation of soul and body, developed the notion of the soul as the essence of a thing or living being. In Aristotle, for example, cutting was the essence of a knife and, following the same logic, the essence or soul of a human body was rational activity. Platonism and Aristotelianism flourished for centuries in the Western hemisphere and gradually entwined with Christian theology, particularly in scholasticism, to produce variable articulations of the self based on the ideas of essence or soul.

In the 17th century, Descartes criticized classical and scholastic philosophy and formulated his cogito as a response. Descartes (1637/1996) founded a new philosophy on a skepticism applied to received, doubtable, and conjectural knowledge. He argued that sense perceptions and received knowledge can be ambiguous or suspect, and are therefore insufficient to found a philosophy seeking absolute truth. Descartes' skeptical approach left him doubting everything except the very fact of his doubting. His new philosophy, therefore, was founded on the self-present consciousness that thinks and doubts, or the cogito. In Meditation II, Descartes argued that the proposition "I am" or "I exist" is necessarily true when put forward by a mind that conceives itself as such, and is therefore a reliable foundation for philosophy. The cogito, or thinking self, became the only rational basis of knowledge and was differentiated from the body, extensive reality, or matter. The thinking mind and the objects of extensive reality were henceforth two distinct ontological categories, the latter being perceived and acted on by the former.

Dussel (2003) explains that Descartes' separation of the mind from the body was firmly embedded in a European conceit that claimed a god's eye view of the world removed from any spatial or historical coordinates. Throughout the Enlightenment period, he argues, Europeans usurped the power once attributed to an all-seeing and all-knowing god, endowing themselves with a subjectivity in a paternalistic relationship to the material world and non-Europeans others. For Dussel, the image of the conscious mind acting on an innate matter was also predicated on the prevalent colonial attitudes of the 1500s during Europe's rise as an imperial power. Alcoff (2012) emphasizes that for Descartes and European modernity in general, "the knowing I is imagined to be both universal arbiter and neutral or perspectiveless observer and as such need not give an account of its own prejudgments or accord presumptive authority to others” (p. 63).

The production of a European consciousness free of historical and material tethering and endowed with an beyond-doubt existence shot through with a sentiment of mastery justified much of the invasiveness of this philosophy throughout Europe's colonies. As the spread of colonialism and Western philosophy intensified, so too did racist discourses that differentiated between a normative white or European subject and those marked by differences in skin, hair, and bone and categorized as other (Du Bois, 1897/1970).

Throughout the 18th and 19th centuries, during the years of war between colonial and Indigenous nations in North America and worldwide, Western idealist philosophers such as Kant (1781/2003), as well as empiricists such as Hume (1740/2003), wrestled with the notion of a unified self and its relationship to empirical reality, the body, spirit, and god. Kant proposed a critical philosophy in which subjective experience was understood in terms of universal or transcendental structures whereby consciousness had subjective awareness of objects in the 
International Journal of Child, Youth and Family Studies (2015) 6(4): 595-621

world through representations. However, Kant participated in a growing anthropology based on racial taxonomies, and privileged these "universal” structures of consciousness and reason to "men”, which he understood as white and civilized (Eze, 1997). Hume, contrary to Kant's transcendentalism, foreclosed the possibility of a consciousness that unifies or underlies the multiplicity of sense perceptions that constitute temporal experience. Hegel (1807/1998), a starting point for teleological thinking about self-consciousness, viewed individual and social consciousness as a necessary and progressive development of spirit.

Following another century of dialogue in philosophy, and the continued spread of European philosophy and dominance across the globe, the conversation on the self shifted again within Western thought through what Ricoeur (1970) called "the school of suspicion” (p. 32). The Cartesian self (Descartes, 1637/1996), he argued, received its most sustained critiques from the masters of suspicion Nietzsche, Marx, and Freud. Nietzsche rethought the self in terms of its history and embodiment, whereas Marx returned consciousness to material conditions of life and class, and Freud posited an ego wrenched between bodily drives and cultural rules. While the concept of the self has had a rich history and undergone enormous criticism, the self in CYC has generally coalesced around notions of reflexivity, essence, authenticity, morality, awareness, and presence, all of which can be traced through dominant European thought. In the next section I engage with an assemblage of literature which I believe has been central to thinking about the self in CYC and continues in the Western philosophic tradition. I then provide a short critique of this literature and attempt to think through how we as a field might address some of the problems facing contemporary children, youth, and families through a more politicized notion of self and praxis.

\section{The Canonical Self}

The canonical self is a concept I developed to help me think through a central portion of the CYC literature related to the self. For me, the canonical self is an aggregate of the writings of a small group of CYC theorists that together constitute the dominant conceptualization of the self in the field's literature. The canonical self, as I have thus far demonstrated, is for me situated within the historical development of CYC and European philosophy more generally. The main authors who contributed to this canonical body of literature, and who have thus come to hold a place of authority in articulating the self for the field, include Frances Ricks (1989, 1993, 2001), Thom Garfat (1998, 2003; Garfat \& Charles, 2007; Garfat \& Ricks, 1995), Gerry Fewster (1990, 1999, 2010), and Mark Krueger (1991, 1994, 1997, 2009). Many other individuals in North American have contributed to CYC's rendition of the self; however, the texts of these four authors constitute what I believe to be the canonical literature.

These canonical authors who wrote prolifically during the 1980s and 1990s - and in some cases continue to do so up to the present day - were influenced by other innovators in the CYC field and other disciplines, such as Henry Maier (1979, 1987, 1995), Michael Baizerman (1974, 1994, 1995), Edna Guttmann (1991), Fritz Redl (1966; Redl \& Wineman, 1952), Jerome Bruner (1990), and Karen VanderVen (1979, 1999). Combined, these theorists have worked for over 50 years to articulate a foundational theory of self and its relationship to CYC. The relationships between the self and knowledge and practice in CYC primarily include self-reflection, presence, 
International Journal of Child, Youth and Family Studies (2015) 6(4): 595-621

and authenticity. Within the canonical discourse, understanding and articulating the self has come to be understood as necessary for effective, ethical, relational, and professional practice.

Although the self is described with some variability in the canonical texts, the authority imbued to these authors, their intra-group referentiality, use of personal experience as evidence, shared assumptions around individuality and introspection, reflexive rather than definitive articulations, and depoliticized understanding of the self all constitute the canonical nature of the self. Nealon and Giroux (2012) explain that "to be an author in the canonical sense is to be invested literally with author/ity, to be taken seriously and even revered for your accomplishments” (p. 11). It is in reference to the issue of authority as it is employed in relation to particular articulations of the self that the canonical self emerges and necessitates critique.

Importantly, I am not standing outside of this particular CYC tradition to level a critique: I was trained through these canonical texts, have engaged with them thoroughly in my education and practice, and consider myself to be, in some small way, part of a new generation of selftheorists in CYC. My interest here is to use the canonical notions of self-reflection and questioning assumptions to interrogate the very foundations of our thinking on the self. I work at this project from within the very discourse that I seek to open up. As such, I perform a doubling practice which Lather (2001) describes as simultaneously working-within and troubling-fromwithin. This type of conservative transgression is a double gesture that depends on a shared horizon yet gives new inclinations and twists to those shared lines. I therefore sample from the CYC literature in order to provide a reading that I feel moves us in a direction more accountable to our contemporary circumstances. I emphasize the depoliticized nature of the self in its canonical form in order to work towards a notion of politicized praxis as a shared horizon of possibility.

\section{The Canonical Literature}

\section{Gerry Fewster}

Gerry Fewster (1990, 1999, 2010) is one the most visible figures in articulating a CYC perspective of the Self. Fewster (1999) generally capitalizes the "S" in Self and describes it variously as the experiencing of a unique perspective, an inner voice or real essence, and "a mind-boggling notion that urges me to come to terms with my place in the cosmos” (para. 2). In the company of Frances Ricks, Mark Krueger, and Thom Garfat, Fewster has literally written the book on the self in CYC. His first major work, 1990's Being in Child Care: A Journey into Self, which is cited in nearly all the works of the other canonical writers, argues that the experience of self is the heart of CYC practice. Although he draws consistently on psychological theories, he also critiques them and works on a perpetually evolving theory that integrates psychology, new age theory, and science with his personal experience.

Moving back and forth between theories of the self and his lived experience, Fewster (1999) intertwines the intellectual and the reflective with examples from his practice with children and youth. In terms of relationships, he explores the paradox of needing autonomy for relatedness, stating that "the more I am able to experience my Self as a separate and unique 
International Journal of Child, Youth and Family Studies (2015) 6(4): 595-621

being, the more I am able to become an active participant in seeking, creating, and sustaining my relationships with others - and vice versa” (para. 3). He also explores the mind-body connection via his training in Western psychology, his forays into new age experience and energetics, and his ongoing work to hear his internal voice. Fewster shares the insight that, "when my mind opens up to what my body already knows, I will be free to become all that I am” (para. 34). It is important to Fewster to continually reconceptualize the self in the light of new experience, to seek empirical evidence for the self, and to explore the utility of concepts and evidence for working with the self. In the end, he suggests that "the Self emerges through direct contact with other Selves” (para. 52).

In his most recent major work, Don't Let Your Kids Be Normal, Fewster (2010) reduces political, ideological, and environmental constraints on human development to projections of individual psyches inundated by fear. In other words, the social here is reduced to the Self. Rather than changing the contexts in which development takes place, Fewster argues, developing curiosity, compassion, caring, and awareness at the individual level are primary to solving society's ills. Only the recognition of an authentic self within each parent and child can intercede in the intergenerational transmission of fear that catalyzes hostility and insecurity worldwide. Fewster places unprecedented responsibility on parents for their lack of personal development that, in turn, interferes with their children's inherent development potential. On the other hand, Fewster reassures parents about their natural belonging in this world, their authentic selves, and provides a practical avenue for personal and intergenerational healing. This healing, he argues, is available only through consciousness raising and authentic relationships based on the universal communication systems of intuition and energy.

In a Rousseauian turn, Fewster (2010) claims that children inherently know what they need to develop, and that it is only adult fear, projection, and rejection that stifle children's growth. In his view, parents make individual choices that allow the mythology of medical diagnosis and the practices of pharmaceutical companies to maintain power over their children. Here again, he reduces social phenomena to failures in parenting, a reading of the social order that does not account for issues of power, structures, or discourse related to economic or political systems. Fewster locates himself within the psychological establishment, which he renders as a soulless enterprise incapable of meaningful relationship. Again, however, he holds out a glimmering piece of salvation in the form of a reading of quantum theory that offers a radically new vision of reality in which humans are an integral and purposeful aspect of the cosmos.

\section{Mark Krueger}

Mark Krueger (1991, 1994, 1997, 1998, 2009) has been acknowledged for his lifelong direct work with youth, as well as his literary and theoretical contributions to CYC. Krueger (1997) extrapolates insights from research contexts to explore how using presence in CYC work often employs stories as a frame. Krueger explains that self-understanding, including knowing one's feelings and consciousness, can deepen "understanding of the meaning of what is occurring" (p. 154) and " the subjective world of the child by sharing the road to self-discovery" (p. 154). This author contends that CYC workers frame experience in stories, integrating three sets of thoughts: (a) the uniqueness of the story due to the worker's presence in it; (b) the 
International Journal of Child, Youth and Family Studies (2015) 6(4): 595-621

existence of the story achieved through recollection; and (c) the interpretation based on familial and cultural experience. In describing the self as a reflective and interpreting being that can come to understand itself in the process of storying experience, Krueger (1997) highlights the regular practice of using experiential approaches to think about CYC work. He emphasizes the subjective nature of storying and CYC work, while noting that some sort of objective accuracy is also possible through the reflective process.

Although Krueger (1997) posits a cultural and familial component to the practice of telling and interpreting stories, there is insufficient acknowledgment, I believe, of the power and structures that allows one to be a legitimate storyteller or have a valid interpretation. There seems to be, in Krueger's account, an assumption that an individual can story and reflect on experience relatively independent of economic, unconscious, linguistic, or social factors. While Krueger's earlier work emphasized practitioner meaning-making, more recently he has explored genuineness in human interactions, and he has this to say about his experience: "I had to know self so I could be available to mirror back my experience of the other” (2009, p. 49). Such genuine interactions are predicated on the ability to be present, curious, and sensitive, he says, but at bottom, youth are really "waiting for someone real” (p. 50) to show up. Krueger explains that this "real" person is someone whom they can emulate, some who can be with youth through their own questioning of who they are. The "real" person here is related to an authentic, independent, and timeless individual essence.

\section{Frances Ricks}

Ricks (1989, 1993, 2001), although acknowledging that the concept of the self is amorphous, puts forward three principles of self-awareness: (a) the self is available to awareness; (b) the self-image produced by this awareness is affected by new information and therefore changes; and (c) this changing self-image affects the functioning or behaviour of the self. The self-awareness model that Ricks proposes for CYC contains two major categories: beliefs and style. In her model, beliefs are statements held to be true and style, or "presentation of individuality" (p. 37), are the essence of one's being. Self-awareness is tied so intimately to presence that "presence of self and action of self comes into operation only when one's attention is turned inward, and until or unless that happens, there is no self to be present” (p. 35). Ricks proposes moving beyond a view of self-awareness as summary knowledge of views, values, beliefs, and personal characteristics, toward a more active state or dispositional presence in which being aware is "to act in knowing what is; to be present in that knowing, and taking that presence into action” (p. 34).

For conceptual purposes, Ricks (1989) describes the self as a "combination of being/presenting one's thoughts, feelings and behavioural acts out of one's construction of reality or world view" (pp. 35-36). Ricks describes the self in terms of positions, or configurations within a temporal dimension, that are evident as thoughts, feelings, and acts. These positions are postures of the self and are "bottom line statements of one's being or the essence of who one is” (p. 39). While Ricks argues for increased self-awareness and presence, she also cautions that positions or constructions of reality "are constructed from one's reality and they serve one by maintaining that reality” (p. 39). Self-awareness therefore necessitates critical 
International Journal of Child, Youth and Family Studies (2015) 6(4): 595-621

evaluation of potential deceptions done in a "safe environment for self-awareness discoveries" (p. 40). Once the beliefs, values, attitudes, style, feelings, and actions of a person are brought into conscious awareness at a specific time, then, and only then, is there a being or becoming self. The self, therefore, is provisional, subjective, and transitory, yet at any given moment or position can be thought of as having a specific essence or bottom line.

In the context of practitioner training, Ricks (1993) reflects on the role of a worker's own needs and desires, and their capacity to impose particular interpretations on clients. Ricks proposes a model of practitioner training called therapeutic education to integrate personal growth in curriculum objectives. She argues that CYC training should "adopt a new approach which incorporates a therapeutic element" because "just about every student in a counsellor training program will need help with personal issues if they are to be effective in their work" (p. 22). Ricks proposes a complete reworking of departmental values and structures to accommodate an educational approach that centres the student's personal growth needs. She ties the therapeutic education model to the KSS model and explains the conjunction as a process whereby personal learning supports the learning of others, individual differences are attended to, and trust and care are central to the learning process. Positing the development of self as the focus of education, Ricks argues that, "educators must have clarity about the self and how to assist students in inquiring and discovering the self whether they are teaching research or intervention methods" (p. 33).

In her 1989 model of self-awareness, Ricks takes up the idea that being present to the other (client) is impossible without being present to the self (practitioner). She goes so far as to claim that "to know about the client requires being aware of self since the client only exists out of one's self experience of the other person" (p. 35) and that "without self there is no other" (2001, para. 1). Stated like this, self-awareness borders on solipsism and subjective idealism. Ricks, however, is specifically speaking to the awareness of the practitioner rather than to the actual physical existence of other people. From the outset, she puts forward self-awareness as a precondition for being accountable to the children and families that CYC practitioners work with. Almost 20 years after Ricks put forward the self-awareness model, she, with Hoskins, returned to the idea of understanding otherness and difference through the lens of self-awareness.

While the early writings of Ricks parallels the emphasis on self-reflection and authenticity to the minimization of social factors, Ricks and Hoskins (2008) situate their investigation into self and the experience of difference within a dynamic and shifting globalized world. They argue that, "due to globalization and increased connectedness, people are challenged to re-examine old assumptions about differences as expressed through language” (p. 283). The authors explore the challenges inherent in engaging with the complexities of difference and argue for a raised level of consciousness in CYC practitioners. They contend that differences themselves must be more consciously appraised and that practitioners must better understand their relationship to differences. Building on the self-awareness model, the authors conclude that negotiating difference is a process of "coming to terms with one's self” (p. 285) through selfobservation and co-created consciousness. 
International Journal of Child, Youth and Family Studies (2015) 6(4): 595-621

In describing self-observation and co-created consciousness, Ricks and Hoskins (2008) explain that individuals build rational frameworks, or construct systems, to interpret, organize, and manage the complexities of life. These construct systems rely on assumptions, beliefs, biases, and interpretive schemes to assimilate information, make sense of reality, and provide choices for action. When engaging with difference, however, our construct systems are challenged and possibly threatened because our basic assumptions and beliefs are not attuned to all of these new experiences. There is a tendency, Ricks and Hoskins contend, for individuals to withdraw from the experience of difference because of the perceived threat to their construct framework, sense of self, or professional identity. Conversely, however, sophisticated selfobservation and co-created consciousness are alternative approaches to engaging with difference.

A sophisticated self-observer, Ricks and Hoskins (2008) explain, has the capacity to incorporate knowledge of how the interaction among self, other, and context affects their experience and understanding of the world. Co-created consciousness, accordingly, is a process of taking a stance in relation to others, while at the same time deconstructing the beliefs, assumptions, and values that underlie that stance. Constructing and deconstructing experience is a collaborative effort in which understandings are shared, explored, and questioned (Ricks \& Hoskins, 2008). The self in this rendering is an ongoing and situated complexity that weaves history, context, and relationships into a reflexive engagement with other. Ricks and Hoskins conclude by remarking that, not only is this perspective infinite in the "possibilities for creativity, communion, and compassion," it also "demands from everyone the capacity to be helpful and merciful in understanding themselves and others in the moment” (p. 307).

This co-created matrix in which self, other, relationships, and ways of being creatively emerge from conscious relationship opens enormous possibility and dynamism in CYC practice. The model generally puts difference at the centre, whereas models of professionalization and credentialing seem to centre standardization and similarity of competence and ability. This more recent writing demonstrates a subtle shift in CYC literature towards more relational and sociallyinflected accounts of the self.

\section{Thom Garfat}

In "Four Parts Magic: The Anatomy of a Child and Youth Care Intervention”, Garfat (2003) analyzes the therapeutic moment of CYC interventions and uses practice examples to demonstrate how interventions take place through noticing, connecting, giving meaning, and speculating on the meaning-making of others. He then goes on to explain how "checking-in with self” (p. 8), "monitoring self-presentation” (p. 11), and "the utilization of self” (p. 12) are all processes that occur throughout the interventive process. Checking in with self is explained as a self-awareness of one's own experience and the assumptions and constructs that structure meaning. The monitoring of self-presentation is the process of scrutinizing one's external self, including behaviour, body, and interactions, and how they might impact others. For Garfat, the utilization of self involves the intentional actions a practitioner makes "using some characteristic of herself or her experience to influence the process of intervention” (p. 12). Some examples of these characteristics are exposing emotional experience, appearing confused, or showing 
International Journal of Child, Youth and Family Studies (2015) 6(4): 595-621

annoyance. Garfat explains that to use the self, one needs to be in touch with experience, understand one's presentation, and have insight into the impacts of presentation and use of self.

In terms of relational practice, Garfat (2008) describes the self as individual existence, but positions CYC practice as a relational endeavour that manifests in the joining of self and other in the performance of a co-created "in-between" (p. 9). The in-between he describes contains both self and other in an interconnected and synchronized "we" where both selves are maintained. As the context for a CYC relationship and healing, the in-between is relational in the sense that it refers to the experience of self and other in the interaction and doing of relationship. Relational practice, for Garfat, although distinctively attentive to in-the-moment presence, also necessitates a monitoring of self and a check-in with other.

Borrowing the metaphor of the self as a lens for viewing the experienced world from Ricks (1993), Garfat (2008) puts forward the idea of a "perceiving self” (p. 10) and asks us to turn our lens on our self and our experiences. He asks the reader to ponder who we are, how we know ourselves, and what the limits are to our full engagement of self. He explores the self as the experience when we have our reflection turned on itself. The self in this rendition is therefore the observer, the instrument of observation, and the observed. The self is able to know itself, but is also self-limiting in the sense that it makes decisions regarding which perspectives it is attuned to and which it cuts off. These choices of perspective therefore structure the experience of self, other, and the in-between, and can limit connection. Garfat, however, also proposes transcending these limitations of perspective and connection through "the purity of self that is present in the in-between” (p. 11). The in-between provides the opportunity to experience self through relationship with other, and in a truly connected relationship, the guarded self is said to be cast aside and the real self honestly exposed.

In "How Am I Who I Am? Self in Child and Youth Care Practice", Garfat and Charles (2007) explicitly attend to presence, authenticity, and training practitioners in reflective practice through attention to the self. In their presentation of the theory of self, Garfat and Charles rely primarily on the views articulated by Ricks (1989), Fewster (1990), and their own previous individual publications. They speak of the influences of culture, time, personal experience, and history on definitions of the self, yet do not situate their rendition of self in any of these domains. These authors continually recognize a difficulty in expecting a situated self to define itself, yet deliver a singular and final definition.

Garfat and Charles (2007) begin their exposition of the self by claiming that, "it would be an understatement to say that the self is central to Child and Youth Care Practice” (p. 6). Next, they relate the idea of self to the concepts of context, being, other, and responsibility. Their concept of the context of self is underdeveloped except for some indication that a "true individual self" exists that mediates all experience, yet is only knowable within "the vulnerable context of an intimate relationship" (p. 6). The authors maintain that the self, as a way of being, is manifest as a presence in relationship rather than as a tool, technique, or strategy. On the one hand they posit a true authentic self at the core of every individual, while on the other they contend that this self is a dynamic way of being that is manifest through an aware and present engagement with others. The self is, therefore both "the centrality of that which we are" (p. 7) 
International Journal of Child, Youth and Family Studies (2015) 6(4): 595-621

and constituted through relationship-based constructions of meaning such that "that we grow and change while constantly redefining who we are in the moment” (p. 6). The gradual move towards relational accounts of the self, I believe, sets a path towards beginning to more fully theorize social factors in our conceptualizations.

\section{The Ethical and Moral Self}

Garfat and Ricks (1995) raise the question of the relationship between doing right and being effective in CYC, and also introduce the concept of context into the ethical decisionmaking process. Their self-driven model of ethical decision-making holds that the self of the practitioner informs and mediates the application of ethical codes and standards in specific contexts of practice. The self in this model includes the values, beliefs, and abilities of the worker, which interact with unique situations to resolve problems that can inform future ethical deliberations. The focus is on a responsible and self-aware individual who moderates ethical practice rather than "being driven by external variables" (p. 397). According to Garfat and Ricks, the attributes necessary for a functional self-driven ethics include: (a) a knowledge of self defined as an awareness to how values, beliefs, and previous experience act to inform current experience; (b) critical thinking skills, including the capacity to identify and challenge assumptions and the role of context; (c) consideration for alternative choices; and (d) utilizing evaluation and feedback. Throughout their description of the self-driven model, the authors position the practitioner as the mediator of ethics and the dispenser of ethical choices on a client. Although they emphasize the unique context of every ethical dilemma, this model lacks consideration of the client's choices, values, and beliefs. The self-awareness model determines values as feeling-based, thoughts as belief-based, and ethics - or the rules for what one should and should not do - as based in the ability to analyze what one does in the world.

Building on the self-driven model of Garfat and Ricks (1995) and attending more to others in ethical decision-making, Ricks and Bellefeuille (2004) put forward the concept of concerned responsiveness. They argue that concerned responsiveness and the participatory inquiry approach inherent in it bridge the concepts of knowing self and attending to the other and include negotiating values, incorporating different voices in constructing the problem, subjecting personal beliefs and knowledge to scrutiny, and co-creating the context of care. Ricks and Bellefeuille also prioritize critical analysis as central to ethical practice. Leading with the assumption that “internal maps of reality” (p. 118) shape practitioners' perceptions and interpretations, they argue for an ethical stance of not-knowing or of being curiously engaged with the unknown. A stance of inquiry and not-knowing therefore challenges practitioners to rediscover the ethical and the self in the shifting and unique context of every experience.

White (2005) continues in this line of emphasizing the role of the self and context in practice ethics. She posits that ethical caring depends on "the development of an ideal self . . . in congruence with one's best remembrance of caring and being cared-for” (p. 13). Agreeing with Ricks and Garfat (1995), she highlights the personal and context-based character of ethical deliberation while also emphasizing the impact and involvement of an individual's personal history. Her approach to ethical decision-making assumes a self that is temporally positioned between a personal historical narrative and an imagined future self. By 2007, White had 
International Journal of Child, Youth and Family Studies (2015) 6(4): 595-621

developed her conception of ethics through a praxis model that highlights the political, social, and moral character of practice.

\section{Metaphors of the Self}

Although concepts of the self abound in CYC literature, they have received little comprehensive review or classification. Marie Hoskins, a professor in CYC at UVic, has, however, investigated the self as a concept in counselling theories and her texts are used in SCYC curriculum. I was introduced to Hoskins and Leseho's (1996) “Metaphors of the Self: Implications for Counselors" in my undergraduate studies at SCYC and the article became influential in my appreciation of the diversity of theories of the self among human service practitioners. In the article, Hoskins and Leseho analyze the prevalent theories of the self in counselling literature in terms of their metaphoric articulations, categorize these metaphors as either traditional or postmodern, and elaborate practice implications. Categorizing various metaphors as traditional or postmodern, they refer to the unitary self, the integrated self, the narrative self, possible selves, the empty self, and internalized selves.

The two traditional perspectives of the self that Hoskins and Leseho (1996) begin with, the unitary and the integrated, reflect a description of the self as an enduring autonomous core, in the case of the former, and a higher cohesive authentic self in the case of the latter. The unitary self is analogous, they contend, to an artichoke with a psychic fingerprint at its core: It is vulnerable when it is young and develops protective layers as it interacts and adapts to an outer world. These protective layers, however, are not the true self, and the goals of counselling and development, from this perspective, include discarding aspects of the self that do not relate to the true core, and finding a sense of cohesion in life. The integrated self, while similarly positing an essence or authentic core, does not contend that the protective layers need to be peeled back, but rather integrated. Those who write about the integrated self, such C. G. Jung, believe in a higher actualized self and that the path to that cohesive and authentic whole is through the integration of all aspects of oneself. Hoskins and Leseho offer a board of directors as a metaphor for this view, describing the self as the board's chair and the other aspects of the personality as members of the board. The work of human service practitioners, from this perspective, is to find how the disparate pieces of a client's life can be brought together into a whole.

The postmodern perspectives that Hoskins and Leseho (1996) summarize include the following: the narrative self as comparable to an author who uses language and stories, both personal and cultural, to engage in an ongoing process of narration; possible selves as a bridge between past and future events, which are shaped by socio-cultural influences; the empty self as a holograph, which is incapable of connecting with history or spirituality due to current consumerist culture; and the internalized selves perspective, which is broken down into a community of selves metaphor and a dialogical self metaphor. The community of selves metaphor is similar to the integrated self view of traditional psychology, but Hoskins and Leseho insist that within this view, there is less of an organizing centre and more of a cooperative diversity of voices. The dialogical self is reminiscent of a theatre performance with a variety of characters, dialogues, dramas, and acts representing the complexity, interdependence, and polyvocality of self-organization. 
International Journal of Child, Youth and Family Studies (2015) 6(4): 595-621

The self in this rendering is a synthesizing process that does not unify the diversity and complexity, as in the integrated metaphor, but rather organizes and balances the plentitude of autonomous characters in the play. What Hoskins and Leseho offer us is attention to the diversity of ways that the self can be conceptualized and how being accountable to the discourses we use is necessary for practice. The authors argue that practitioners are guided in their approaches by the metaphors of the self to which they have access; therefore, the metaphors themselves recirculate as social activity.

\section{Reflections on the Canon}

What I have termed the canonical self, an aggregate of a small number of theorists' writings in the field, plays a central role in educating students as to what a self is and how it is developed and used in practice. There is some historical precedent for the canonical self, such as the desire to include a concept of personhood and a professional self into a practice-based academic discipline. However, the concept of the self, as it is articulated in the canonical texts, has not shown itself to be in any way necessary, natural, substantiated, or obvious. Adding the term canonical when referencing the concept of the self as articulated in core CYC literature has both helped me to locate it within a particular history. It has also helped me to undo some of the reifications that go along with the notion of the self by considering it specifically as a concept and moreover, $a$ concept among many possible concepts.

Although the concept of the self has a central place and rich history in CYC, its definition, explication, and adequacy continue to be debated on a number of related fronts. First, equivocation: The concept has been defined a number of ways across time and this multiplicity is shrouded by the single term self. In the CYC literature, there is a tendency to draw on a variety of philosophic and psychological theories for conceptualizing the self, but the tensions, nuances, and complexities of these different traditions are not always engaged with. The second and connected issue is contraction. With the concept's almost innumerable relations to political, sociological, and psychological theory, many important considerations have not yet been dealt with in CYC formulations.

Finally, with regard to the issues of critique and proliferation, the validity and adequacy of the concept of the self has been significantly challenged in the humanities and social sciences in the past century. Social constructionist (Gergen, 1991), feminist (de Beauvoir, 1949), queer (Britzman, 1995, 2009; Butler, 1997, 2004), post-structural (Derrida, 1976, 1978; Foucault, 1978, 1980, 1988; St. Pierre, 2000), Indigenous (Watts, 2013), and post-colonial (Dussel, 2003; Fanon, 1961/2004, Spivak, 1976) perspectives, among many others, have variously critiqued, rejected, and/or deconstructed the concept of the rational and internal self. Such critiques or alternative ways of knowing have given rise to a plurality of divergent and competing concepts, such as those of identity, subject formation, being, place-based existence, singularity, and subjectivity.

This ongoing critique and proliferation of concepts challenges static notions of the self and provides rich opportunities for dialogue. This article provides a first gambit in such a critical 
International Journal of Child, Youth and Family Studies (2015) 6(4): 595-621

dialogue by elaborating the concept of the self as it has been rendered in CYC's central texts. By identifying critiques and problems with our current conceptualizations I hope to hint at some of the possibilities for rethinking the self in terms of a contemporary politicized praxis.

I argue, following Yoon (2012), that with the increasing diversity of CYC students and CYC service recipients in Canada, it may be time to rethink and critique our central concepts. While critical theories, feminisms, post-structural and continental philosophies, and Indigenous ways of knowing may provide new directions for thinking about the self in CYC, an elaboration of these possibilities is beyond the scope of this article and hereafter I therefore specifically focus on the adequacy of the concept of the self for addressing or conceptualizing social and contextual factors in contemporary Canadian society. To address some of these issues, I turn now to the praxis model that superseded the KSS model at SCYC and I further suggest approaches to making CYC more responsive to the current Canadian context.

\section{The Praxis Model: Knowing, Doing, and Being in Context}

At the turn of the 21st century, the concept of self was so thoroughly integrated in CYC that Garfat and Charles (2007) claimed "it would be an understatement to say that self is central to Child and Youth Care Practice” (p. 1). Furthermore, as professional competencies and curriculum standards began to take root across North America, the self was transposed from its theoretical origins into much more substantial, powerful, and overarching frameworks. The concept of the self, however, over the period of its expansion and transposition, was not articulated in a unitary way. In 2007 another important transition point occurred as the knowledge, skills, self or KSS model was changed to the CYC praxis model. I believe a new period is on the horizon in which the praxis model can provide a basis for radically rethinking and politicizing concepts of the self and thereby more adequately responding to contemporary issues.

Despite the existence of other conceptual frameworks throughout CYC's relatively brief history as an academic discipline, the KSS model was the leading framework at SCYC from its inception in the 1980s. Recently, however, the KSS model was extended and superseded by the praxis framework, which is now the central framework at SCYC. In 2007, Dr. Jennifer White, associate professor in CYC at UVic, published the groundbreaking article "Knowing, Doing and Being in Context: A Praxis-oriented Approach to Child and Youth Care”. Following White's publication, the praxis framework quickly replaced the KSS model in course readings and field handbooks at SCYC. White (2007) recognized the need for a more dynamic framework that could "adequately represent the complexities of everyday CYC practice, while also offering a practical tool for critical reflection and analysis” (p. 225). White also provided a critique and new rendition of the concept of the self as being or ways of being.

While the praxis model retained many of the older notions of the reflexive self in action and the integration of theory and practice in the application of self-understanding, White (2007) also proposed a more embodied, embedded, and narratively informed understanding of the self, or what she called being. Knowledge, skills, and self became knowing, doing, and being in 
International Journal of Child, Youth and Family Studies (2015) 6(4): 595-621

White's work, which emphasized the active and dynamic nature of the three concepts (see Figure 1 below). White referenced many of the self theorists of the 1990s, such as Ricks (1989), Fewster (1990), Krueger (1997), and Garfat (2004), while also emphasizing the difficulties of representing in words the embodiment and expression of values, ethics, habits of thought, and ways of being. White articulated the notions of being with and knowing how to be in her conceptualization of being, and provided some examples of ethical approaches and habits of mind for effective CYC. The qualities she articulated included the following: mindful and selfaware; relational and collaborative; curious and open; caring; situationally immersed; and inclusive. White inaugurated a shift in the conceptual landscape at SCYC and provided a new framework for thinking about CYC in a more dynamic, embodied, and contextualized way.
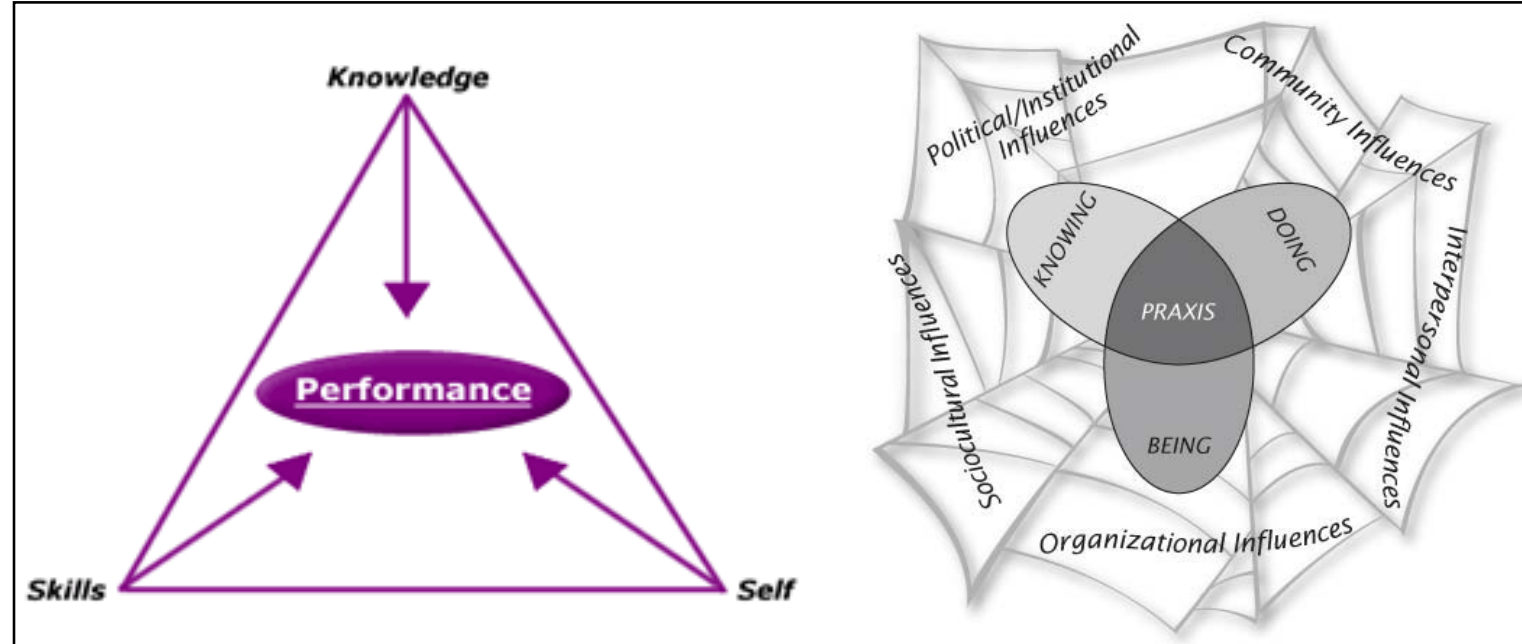

Knowledge, Skills, Self

Praxis

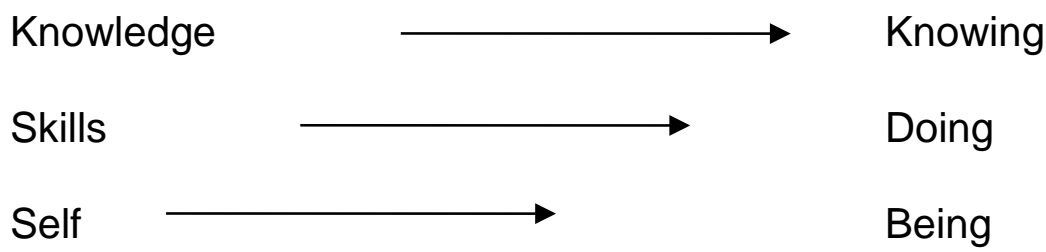

Figure 1. The praxis framework. 
International Journal of Child, Youth and Family Studies (2015) 6(4): 595-621

Illustrated as a web, White’s (2007) praxis framework, on the right, highlights the active and contextualized aspects of the "knowledge, skills, self" framework, which is illustrated on the left as a triangle.

The praxis framework provided a situational, complex, and dynamic understanding of CYC that challenged both the notion of a static self and a standardized CYC. At SCYC, the praxis framework introduced a new vocabulary for articulating the relationship between theory, practice, and self, and challenged students, instructors, and professors to rethink CYC. As an undergraduate student at SCYC from 2007 to 2011, my academic beginning coincided with the introduction of the praxis framework, and I experienced first-hand the excitement and challenge of thinking through CYC as a praxis. I had been interested in ideas of the self prior to starting at the school, and the conversations that were happening around praxis during my undergraduate studies further motivated me to conceptualize my work in terms of a way of being and a contextualized integration of theory and practice. Furthermore, I was inspired by a number of CYC scholars (e.g., de Finney et al., 2011; Gharabaghi \& Krueger, 2010; Skott-Myhre \& SkottMyhre, 2011) who extended White's model or developed their own notion of praxis to emphasize the political and revolutionary aspects of CYC. White's praxis framework supported my early conceptualizations of the self in CYC (Kouri, 2010) and generally inspired my practice and research interests. Now I argue that reconceptualizing the self within a politicized praxis framework is imperative for contemporary North American CYC.

\section{Politicized Praxis and the Canadian Humanscape}

Post-secondary education, particularly human service training programs such as CYC, are increasingly being understood as responsible for preparing citizens to participate in our world of unbalanced internationalization, legacies of colonialism, and ideologies that support inequity (Jorgenson \& Shultz, 2012). In Canada, visible minority, Indigenous, and immigrant populations are consistently, yet differentially, found to be impacted on health and economic outcome measures (Pendakur \& Pendakur, 2011; Veenstra, 2013; Wu, Noh, Kaspar, \& Schimmele, 2003), disproportionately involved with foster care (Assembly of First Nations, 2008; Statistics Canada, 2011a), and underrepresented in political decision-making processes (Black \& Erickson, 2006).

Given the rapidly growing diversity of children, youth, and families in Canada, spurred in part by increasing immigration from outside Europe and high birth rates in Indigenous and racialized minority groups (Statistics Canada, 2010, 2011b), attending to disparities is critical.

Traditional models of CYC that inform national curricula and practice standards are grounded in assumptions of individualism, meritocracy, objectivity, and cultural essentialism, and they do not adequately represent or respond to the realities and experiences of diverse Canadian populations (de Finney et al., 2011; Yoon, 2012). Contemporary CYC must develop alternatives to individualizing and essentializing approaches to care and elaborate strategies that address inequitable social realities (de Finney, Little, Skott-Myhre, \& Gharabaghi, 2012; Gharabaghi \& Krueger, 2010; Kivel, 2007). Tyyskä (2009) argues that rather than reducing the interplay of complex social and identity factors to single-issue approaches, a broad perspective 
International Journal of Child, Youth and Family Studies (2015) 6(4): 595-621

inclusive of social, political, and economic features is necessary to prepare practitioners for contemporary practice. Research in CYC (e.g., de Finney, 2010; di Tomasso, 2012; PaciniKetchabaw, 2007) suggests practice approaches that conceptualize and respond to differential experiences of inequity related to identity and socio-cultural factors are important for improving practitioner responsiveness to Indigenous, racialized, visible minority, immigrant, and marginalized children and youth.

Although CYC has traditionally been committed to providing contextualized care through direct practice, there are significant gaps in current CYC models. To better respond to Canada's rapidly changing populations, CYC requires new models of practice that integrate research on socio-cultural processes, inequity, power, and identity. I believe we need to question how CYC can better respond to today's diverse child and youth populations by critically revising our foundational philosophies, questioning professional roles, and politicizing praxis. Although Canada's child and youth populations are heterogeneous and impacted differentially by sociocultural factors such as poverty, racism, globalization, and sexism, I argue that a praxis framework that premises these processes and integrates critical theories of identity and society into notions of the self can advance our state of knowledge and practice significantly.

The current leading model in CYC conjoins theory and practice in praxis and defines that praxis as self-aware and accountable action that responds to socio-cultural, historical, and political contexts (White, 2007). While this model offers a language for research and training, it has yet to be systematically linked to research on globalization and neo-liberalism (Burnett, 2004), heterosexism (Morris, 2011), individualization (White, 2011), neo-colonialism (de Finney, 2010), civic education (Claes, Hooghe, \& Dietlind, 2009), representation (Nxumalo, 2012), CYC identity (Kouri, 2012), cultural hegemony (Saraceno, 2012), and/or revolution (Skott-Myhre, 2004; Skott-Myhre \& Gretzinger, 2006). By thoroughly interrogating and updating CYC's foundational concepts of the self and praxis through socio-cultural and intersectional analyses, critical race and gender theories, and anti-colonial frameworks, I believe that we will be able to more adequately respond to contemporary contexts. This article has contributed to this development by outlining how the self and praxis have been conceptualized thus far. As an opening gambit, I hope that this work will inspire us in CYC to critically reflect on our theoretical traditions and move forward towards a praxis that more adequately responds to the realities of contemporary society. 
International Journal of Child, Youth and Family Studies (2015) 6(4): 595-621

\section{References}

Alcoff, L. M. (2012). Enrique Dussel's transmodernism. Transmodernity: Journal of Peripheral Cultural Production of the Luso-Hispanic World, 1(3), 60-68.

Anglin, J. (1999). The uniqueness of child and youth care: A personal perspective. Child and Youth Care Forum, 28(2), 143-150. http://dx.doi.org/10.1023/A:1021945306842

Aristotle. (2008). De anima (R. D. Hicks, Trans.). New York: Cosimo.

Assembly of First Nations. (2008). Kiskisik Awasisak: Remember the children-Understanding the overrepresentation of First Nations children in the child welfare system [PDF document]. Retrieved from: http://www.fncaringsociety.com/sites/default/files/docs/FNCIS-2008-report.pdf

Baizerman, M. (1974). Toward analysis of the relations among the youth counterculture, telephone hotlines, and anonymity. Journal of Youth and Adolescence, 3(4), 293-306. http://dx.doi.org/10.1007/bf02214743

Baizerman, M. (1994). Musings with Mike. Child \& Youth Care Forum, 23(5), 357-358. http://dx.doi.org/10.1007/bf02209068

Baizerman, M. (1995). The secret of life. Child \& Youth Care Forum, 24(3), 209-210. http://dx.doi.org/10.1007/bf02128545

Black, J., \& Erickson, L. (2006). Ethno-racial origins of candidates and electoral performances: Evidence in Canada. Party Politics, 12(4), 541-561. http://dx.doi.org/10.1177/1354068806064733

Britzman, D. (1995). Is there a queer pedagogy? Or, stop reading straight. Educational Theory, 45(2), 151-165. http://dx.doi.org/10.1111/j.1741-5446.1995.00151.x

Britzman, D. (2009). The very thought of education: Psychoanalysis and the impossible professions. New York: SUNY Press.

Bruner, J. (1990). Acts of meaning. Cambridge, MA: Harvard Press.

Burnett, M. (2004). The contemporary policy context of child and youth care: Globalization, neo-liberalism, and the attack on the welfare state. Journal of Child and Youth Care Work 19, 202-206.

Butler, J. (1997). The psychic life of power: Theories in subjection. Redwood City, CA: Stanford University Press.

Butler, J. (2004). Undoing gender. New York: Routledge. http://dx.doi.org/10.4324/9780203499627

Claes, E., Hooghe, M., \& Dietlind, S. (2009). The political socialization of adolescents in Canada: Differential effects of civic education on visible minorities. Canadian Journal of Political Science, 42(3), 613-636. http://dx.doi.org/10.1017/s0008423909990400 
International Journal of Child, Youth and Family Studies (2015) 6(4): 595-621

de Beauvoir, S. (1949). The second sex (H. M. Parshley, Ed. \& Trans.). London: Penguin.

de Finney, S. (2010). We just don't know each other: Racialized girls negotiate mediated multiculturalism in a less diverse Canadian city. Journal of Intercultural Studies, 31(5), 471-487. http://dx.doi.org/10.1080/07256868.2010.513082

de Finney, S., Dean, M., Loiselle, E., \& Saraceno, J. (2011). All children are equal, but some are more equal than others: Minoritization, structural inequities, and social justice praxis in residential care. International Journal of Child, Youth and Family Studies 2(3-4), 361384.

de Finney, S., Little, J. N., Skott-Myhre, H., \& Gharabaghi, K. (2012). Pre-conference roundtable discussion. International Journal of Child, Youth and Family Studies, 3(2-3), 128-145.

Denholm, C. J., Pence, A. R., \& Ferguson, R. V. (1983). The scope of professional child care in British Columbia. Victoria, BC: School of Child and Youth Care, University of Victoria.

Derrida, J. (1976). Of grammatology (G. C. Spivak, Trans.). Baltimore, MD: Johns Hopkins University Press. (Original work published 1967)

Derrida, J. (1978). Writing and difference (A. Bass, Trans.), Chicago: University of Chicago. (Original work published 1966)

Descartes, R. (1996). Meditations on first philosophy, with selections from the objections and replies (J. Cottingham, Ed. \& Trans.). Cambridge, UK: Cambridge University Press. (Original work published 1637)

di Tomasso, L. (2012). More equal than others: The discursive construction of migrant children and families in Canada. International Journal of Child, Youth and Family Studies, 3(23), 331-348.

Du Bois, W. E. B. (1970). Speeches and addresses 1890-1919 (P. S. Foner, Ed.). New York: Pathfinder. (Original work published 1897)

Dussel, E. (2003). Beyond philosophy: Ethics, history, Marxism, and liberation theology. Oxford, UK: Rowman \& Littlefield.

Eckles, F., Carpenter-Williams, J., Curry, D., Mattingly, M., Rybicki, M., Stuart, C., ... Wilder, Q. (2009). Final phases in the development and implementation of the North American Certification Project (NACP) [Draft 1/1/2009]. Retrieved from: http://acycp.org/images/pdfs/Final_Phases_Development_of_NACP.pdf

Eze, G. E. (1997). Postcolonial African philosophy: A critical reader. Cambridge, UK: Blackwell. 
International Journal of Child, Youth and Family Studies (2015) 6(4): 595-621

Fanon, F. (2004). The wretched of the earth (C. Farrington, Trans.). New York: Grove Press. (Original work published 1961)

Fewster, G. (1990). Being in child care: A journey into self. New York: Haworth Press. http://dx.doi.org/10.4324/9781315803975

Fewster, G. (1999). Turning myself inside out: My theory of me. Journal of Child and Youth Care, 13(2). Retrieved from: http://www.cyc-net.org/cyc-online/cyconline-nov2009fewstchapter.html

Fewster, G. (2010). Don't let your kids be normal: A partnership for a different world. North Vancouver, BC: Influence.

Foucault, M. (1978). The history of sexuality. Volume 1: An introduction (R. Hurley, Trans.). New York: Pantheon Books. (Original work published 1976)

Foucault, M. (1980). Two lectures. In C. Gordon (Ed.), Power/knowledge: Selected interviews and other writings, 1972-1977 (pp. 78-108). Brighton, UK: Harvester Press. (Original work published 1976)

Foucault, M. (1988). Technologies of the self. In L. H. Martin, H. Gutman, \& P. H. Hutton (Eds.), Technologies of the self: A seminar with Michel Foucault (pp. 16-49). Amherst, MA: University of Massachusetts Press.

Garfat, T. (1998). The effective child and youth care intervention: A phenomenological inquiry. Journal of Child and Youth Care, 12(1-2), 5-178.

Garfat, T. (2003). Four parts magic: The anatomy of a child and youth care intervention. CYC Online: Journal of the International Child \& Youth Care Network, 50, 1-31.

Garfat, T. (2004). Meaning making and intervention in child and youth care practice. Scottish Journal of Residential Child Care, 3(1), 9-16.

Garfat, T. (2008). The inter-personal in-between: An exploration of relational child and youth care practice. In G. Bellefeuille \& F. Ricks (Eds.), Standing on the precipice: Inquiry into the creative potential of child and youth care practice (pp. 7-34). Edmonton, AB: MacEwan Press.

Garfat, T., \& Charles, G. (2007). How am I who I am? Self in child and youth care practice. Relational Child \& Youth Care Practice, 20(3), 6-16.

Garfat, T., \& Ricks, F. (1995). Self-driven ethical decision making: A model for child and youth care. Child \& Youth Care Forum, 26(4), 393-404. http://dx.doi.org/10.1007/bf02128530

Gergen, K. J. (1991). The saturated self: Dilemmas of identity in contemporary life. New York, NY: Basic Books. 
International Journal of Child, Youth and Family Studies (2015) 6(4): 595-621

Gharabaghi, K., \& Krueger, M. (2010). A new politics in child and youth care. Relational Child and Youth Care Practice, 23(3), 27-39.

Guttmann, E. (1991). Immediacy in residential child and youth care: The fusion of experience, self-consciousness, and action. In J. Becker \& Z. Eisikowits (Eds.), Knowledge utilization in residential child and youth care practice (pp. 65-82). Washington, DC: Child Welfare League of America.

Hegel, G. W. F. (1998). Phenomenology of Spirit (A. V. Miller, Trans.). Delhi. (Original work published 1807)

Hume, D. (2003). A treatise of human nature. New York: Dover. (Original work published 1740)

Hoskins, M., \& Leseho, J. (1996). Changing metaphors of the self: Implications for counselors. Journal of Counseling and Development, 74(3), 243-252. http://dx.doi.org/10.1002/j.1556-6676.1996.tb01860.x

Jorgenson, S., \& Shultz, L. (2012). Global citizenship education (GCE) in post-secondary institutions: What is protected and what is hidden under the umbrella of GCE? Journal of Global Citizenship \& Equity Education, 2(1), 1-22.

Kant. I. (2003). Critique of pure reason (J. M. D. Meiklejohn, Trans.). New York: Dover. (Original work published 1781)

Kivel, P. (2007). Social service or social change? In INCITE! Women of Color Against Violence (Ed.), The revolution will not be funded: Beyond the non-profit industrial complex (pp. 129-149). Cambridge, MA: South End Press.

Kouri, S. (2010). Claiming the self. International Journal of Child, Youth \& Family Studies 1(3), 227-243.

Kouri, S. (2012). Child and youth care to-come. Child \& Youth Services, 3(2-3), 206-236. http://dx.doi.org/10.1080/0145935x.2012.745782

Krueger, M. (1991). Central themes in professional child and youth care. Journal of Child and Youth Care, 5(1), 77-87.

Krueger, M. (1994). Framing child and youth care in moments of rhythm, presence, meaning, and atmosphere. Child \& Youth Forum 23(4), 223-229. http://dx.doi.org/10.1007/bf02209086

Krueger, M. (1997). Using self, story and intuition to understand child and youth care work. Child \& Youth Care Forum, 26(3), 153-161. http://dx.doi.org/10.1007/bf02589382

Krueger, M. (1998). Interactive youth work curriculum. In Interactive youth work practice (pp. 67-78). Washington, DC: Child Welfare League of America.

Krueger, M. (2009). Waiting for someone real. Reclaiming Children \& Youth, 18(1), 49-50. 
International Journal of Child, Youth and Family Studies (2015) 6(4): 595-621

Lather, P. (2001). Postbook: Working the ruins of feminist ethnography. Journal of Women in Culture and Society, 27(1), 199-227. http://dx.doi.org/10.1086/495677

Morris, J. (2011). Doing “sissy” and “tomboy.” In A. Pence \& J. White (Eds.), Child and youth care: Critical perspectives on pedagogy, practice, and policy (pp. 55-69). Vancouver, BC: UBC Press.

Nealon, J., \& Giroux, S. S. (2012). The theory toolbox: Critical concepts for the humanities, arts, and social sciences (2nd ed.). New York: Rowman \& Littlefield.

Nxumalo, F. (2012). Unsettling representational practices: Inhabiting relational becomings in early childhood education. Child \& Youth Services, 33(3-4), 281-302. http://dx.doi.org/10.1080/0145935x.2012.745783

Pacini-Ketchabaw, V. (2007). Child care and multiculturalism: A site of governance marked by flexibility and openness. Contemporary Issues in Early Childhood, 8(3), 222-232. http://dx.doi.org/10.2304/ciec.2007.8.3.222

Pence, A. R. (1989). From conception to fruition: A brief history of the school of child and youth care. Journal of Child and Youth Care, 4(1), ix-xxi.

Pendakur, K., \& Pendakur, R. (2011). Color by numbers: Minority earnings in Canada 19952005. Journal of International Migration and Integration, 12(3), 305-329. http://dx.doi.org/10.1007/s12134-010-0160-6

Plato. (1992, ed.). The trial and death of Socrates: Four dialogues (S. Weller, Ed.). New York, NY: Dover.

Maier, H. (1979). The core of care: Essential ingredients for the development of children at home and away from home. Child Care Quarterly, 8(3), 161-173. http://dx.doi.org/10.1007/bf01554603

Maier, H. (1987). Developmental group care of children and youth: Concepts and practice. New York: Haworth. http://dx.doi.org/10.4324/9781315804217

Maier, H. (1995). Genuine child and youth care practice across the North American continent. Journal of Child and Youth Care, 10, 11-22.

Mattingly, M. A., Stuart, C., \& VanderVen, K. (2010). Competencies for professional child \& youth work practitioners. Milwaukee, WI: Association for Child and Youth Care Practice. Retrieved from: http://acycp.org/2010_Competencies_for_Professional_CYW_Practitioners.pdf

Redl, F. (1966). When we deal with children: Selected writings. New York: Free Press.

Redl, F., \& Wineman, D. (1952). Controls from within: Techniques for the treatment of the aggressive child. New York: Free Press.

Ricks, F. (1989). Self-awareness model for training and application in child and youth care. Journal of Child and Youth Care, 4(1), 33-41. 
International Journal of Child, Youth and Family Studies (2015) 6(4): 595-621

Ricks, F. (1993). Therapeutic education: Personal growth experiences for child and youth care workers. Journal of Child and Youth Care, 8(3), 17-34.

Ricks, F. (2001). Without the self there is no other. CYC Online, 27. Retrieved from: http://www.cyc-net.org/cyc-online/cycol-0401-ricks.html

Ricks, F., \& Bellefeuille, G. (2004). Knowing. Child \& Youth Services, 25(1-2), 117-130. http://dx.doi.org/10.1300/j024v25n01_08

Ricks, F., \& Hoskins, M. (2008). Experiencing differences: The challenges, the opportunities, and the cautions. In G. Bellefeuille \& F. Ricks (Eds.), Standing on the precipice: Inquiry into the creative potential of child and youth care practice (pp. 281-309). Edmonton, AB: MacEwan Press.

Ricoeur, P. (1970). Freud and philosophy: An essay on interpretation (D. Savage, Trans.). New Haven, CT: Yale University Press.

Saraceno, J. (2012). Mapping whiteness and coloniality in the human service field: Possibilities for a praxis of social justice in child and youth care. International Journal of Child, Youth and Family Studies, 3(2-3), 248-271.

School of Child and Youth Care. (2011). Undergraduate student manual. Victoria, BC: Author.

Skott-Myhre, H. A. (2004). Radical youthwork: Creating a politics of mutual liberation for youth and adults. Journal of Child and Youth Care Work, 19, 89-94.

Skott-Myhre, H. A., \& Gretzinger, M. (2006) Radical youth work: Creating a politics of mutual liberation for youths and adults (part II). Journal of Child and Youth Care Work, 20, 110127.

Skott-Myhre, K., \& Skott-Myhre, H. A. (2011). Theorizing and applying child and youth care praxis as politics of care. Relational Child \& Youth Care Practice, 24(1-2), 42-52.

Spivak, G. C. (1976). Translator's preface. In J. Derrida, Of grammatology (pp. ix-lxxxvii). Baltimore, MD: Johns Hopkins University Press.

St. Pierre, E. A. (2000). Poststructural feminism in education: An overview. Qualitative Studies in Education, 13(5), 477-515. http://dx.doi.org/10.1080/09518390050156422

Statistics Canada. (2010). Projections of the diversity of the Canadian population. Retrieved from:

http://www23.statcan.gc.ca/imdb/p2SV.pl?Function=getSurvey\&SDDS=5126\&lang=en $\& \mathrm{db}=\mathrm{imdb} \& \mathrm{adm}=8 \& \mathrm{dis}=2$ 
International Journal of Child, Youth and Family Studies (2015) 6(4): 595-621

Statistics Canada. (2011a). Aboriginal Peoples in Canada: First Nations people, Métis, and Inuit. National household survey. Retrieved from: http://www12.statcan.gc.ca/nhsenm/2011/as-sa/99-011-x/99-011-x2011001-eng.cfm

Statistics Canada. (2011b). Immigration and ethnocultural diversity in Canada. National household survey 2011. Retrieved from: http://www12.statcan.gc.ca/nhs-enm/2011/assa/99-010-x/99-010-x2011001-eng.cfm

Tyyskä, V. (2009). Youth and society: The long and winding road. Toronto: Canadian Scholars' Press.

VanderVen, K. (1979). Towards maximum effectiveness of the unit team approach in residential care: An agenda for team development. Residential and Community Child Care Administration, 1(3), 287-298.

VanderVen, K. (1999). You are what you do and become what you've done: The role of activity in the development of self. Journal of Child and Youth Care, 13, 133-147.

Veenstra, G. (2013). The gendered nature of discriminatory experiences by race, class, and sexuality: A comparison of intersectionality theory and the subordinate male target hypothesis. Sex Roles: A Journal of Research, 68(11), 646-659. http://dx.doi.org/10.1007/s11199-012-0243-2

Watts, V. (2013). Indigenous place-thought and agency amongst humans and non humans: First Woman and Sky Woman go on a European world tour! Decolonization: Indigeneity, Education \& Society, 2(1), 20-34.

White, J. (2005). Earning their trust and keeping them safe: Exploring ethical tensions in the practice of youth suicide prevention. Relational Child and Youth Care Practice, 17(3), $13-21$.

White, J. (2007). Knowing, doing, and being in context: A praxis-oriented approach to child and youth care. Child \& Youth Care Forum, 36(5), 225-244. http://dx.doi.org/10.1007/s10566-007-9043-1

White, J. (2011). Re-stor(y)ing professional ethics in child and youth care. In A. Pence \& J. White (Eds.), Child and youth care: Critical perspectives on pedagogy, practice, and policy (pp. 33-51).Vancouver, BC: UBC Press.

Wu, Z., Noh, S., Kaspar, V., \& Schimmele, C. M. (2003). Race, ethnicity, and depression in Canadian society. Journal of Health and Social Behaviour, 44(3), 426-441. http://dx.doi.org/10.2307/1519788

Yoon, J-S. (2012). Courageous conversations in child and youth care: Nothing lost in the telling. International Journal of Child, Youth, and Family Studies, 3(2-3), 164-186. 